\title{
Predictive outcome measures of adult short stature in patients with severe acquired autoimmune hypothyroidism
}

\author{
Noelia V. Dujovne, M.D. ${ }^{a}$, Natalia A. Gazek, M.D. ${ }^{a}$, Juan M. Lazzati, Biochemist ${ }^{b}$, \\ Mercedes Maceiras, Biochemist ${ }^{b}$,Alicia Belgorosky, M.D. ${ }^{a}$ and Viviana C. Herzovich, M.D. ${ }^{a}$
}

\begin{abstract}
Hypothyroidism caused by Hashimoto's thyroiditis is the most common reason for thyroid dysfunction in children.

Our objective was to analyze its impact on final stature in relation to height and pubertal stage at the time of diagnosis in children younger than 18 years with severe autoimmune hypothyroidism. Out of 79 patients, $78.5 \%$ were girls. Those with goiter $(56 \%)$ had a better height at diagnosis than those without goiter (mean standard deviation score for height: 0.2 versus $-2.42 ; p<0.0001)$. Five girls $(6.3 \%)$ had precocious puberty. When considering the final stature of patients (n:33), among those with short stature at the time of diagnosis, pubertal children had a significantly shorter final stature than prepubertal children (mean standard deviation score for height: -2.82 versus $-1.52 ; p=0.0311$ ). The late diagnosis of severe hypothyroidism in pediatrics has a negative impact on final stature, especially in those who were pubertal patients at the time of diagnosis.

Keywords: hypothyroidism, Hashimoto's thyroiditis, stature, precocious puberty.
\end{abstract}

http:/ / dx.doi.org/10.5546/ aap.2019.eng.388

To cite: Dujovne NV, Gazek NA, Lazzati JM, Maceiras $\mathrm{M}$, et al. Predictive outcome measures of adult short stature in patients with severe acquired autoimmune hypothyroidism. Arch Argent Pediatr 2019;117(6):388391.

\section{INTRODUCTION}

Chronic lymphocytic thyroiditis (CLT) is the most common cause of acquired hypothyroidism in childhood and adolescence; its prevalence is close to $2 \%$ in children and it predominates among females (4:1). ${ }^{1,2}$ The clinical presentation of acquired hypothyroidism is more severe with older age at the time of diagnosis, with greater involvement of final stature. ${ }^{2}$

The bibliography regarding the impact on final stature in children with severe acquired hypothyroidism (SAH) is scarce, so our objective was to detect the patients with greater risk for adult short stature in relation to pubertal stage and height at the time of diagnosis.

\section{MATERIALS AND METHODS}

Descriptive, retrospective study in patients younger than 18 years diagnosed with SAH caused by CLT, seen between 2008 and 2014 at a tertiary care children's hospital.

The inclusion criteria at the time of diagnosis were thyroid stimulating hormone (TSH) level > $50 \mu \mathrm{IU} / \mathrm{mL}$, low thyroid hormone levels for the reference ranges for age, and positive antithyroid antibodies (anti-thyroid peroxidase antibodies [TPOAb] or ultrasensitive anti-thyroglobulin antibodies [TgAb]). Patients with any condition that may have affected their growth were excluded.

The following outcome measures were analyzed: sex, age, height, pubertal stage, bone age (BA) at the time of diagnosis, and presence of goiter in the subsequent visits. Height was described as standard deviation score (SDS) and adjusted for age and 
sex. ${ }^{3}$ BA was assessed by the same pediatric endocrinologist based on the Greulich and Pyle method. Mean parental height was estimated in those patients for whom the height of both parents was obtained.

Tests were done by chemiluminescence; TSH, T3, and T4L using the Architect i4000 platform (Abbott); and T4, TPOAb, and ultrasensitive TgAb using the IMMULITE 2000 platform (Siemens). Previously published reference values were used for TSH and thyroid hormones. ${ }^{4}$ Pubertal development was assessed as per Tanner's methodology, and testicular volume, using a Prader orchidometer. Once diagnosed, all patients started replacement therapy with levothyroxine.

Height was considered close to final stature when the growth rate was less than $0.5 \mathrm{~cm} /$ year and/or adult BA was observed. Short stature was defined as $\leq-2.5$ SDS; normal height, as $>-2.5$ SDS. Patients with height close to final stature were divided into 4 groups:

Group 1 (G1): prepubertal child with short stature.

Group 2 (G2): prepubertal child with normal height.

Group 3 (G3): pubertal child with short stature.

Group 4 (G4): pubertal child with normal height.

An analysis of variance (ANOVA) was done to study the associations among the different outcome measures. The height at the time of diagnosis and the height close to final stature were compared in each group.
The study was approved by the Institutional Ethics Committee, and the comprehensive protection of patient data was warranted.

\section{RESULTS}

A total of 79 patients were assessed; $78 \%$ (n: 62) were girls. The median age at the time of diagnosis was 10.9 years (range: $10-12$ years).

The analysis of the associations among outcome measures showed that patients with goiter (n: 45) had a better height at diagnosis than those without goiter; mean SDS for height: 0.2 versus $-2.42(\mathrm{~T}=-5.13 ; p<0.0001)$.

Final stature was obtained only for 33 patients because, to date, some patients have not yet reached their final stature and others were lost to follow-up (Table 1).

Normal height at the time of diagnosis was observed in 23 patients (G2 and G4); of them, 19 reached a normal height for the population ( 8 within the genetic range and 2 below it; no anthropometric data were obtained about the fathers of the other 9 patients). The remaining 4 patients ended up with short stature due to poor treatment adherence.

Ten patients had short stature at the time of diagnosis, and prepubertal children (G1) reached a significantly higher final stature than pubertal ones (G3) $(p=0.0311)$. The median follow-up of prepubertal children was 6.83 years, while that of pubertal children, 2.5 years.

Table 2 shows the clinical characteristics of G1. The 4 patients reached a normal final stature for the population (SDS: $1.48 \pm 0.37$ ).

TABLE 1. Patients with final stature. N: 33

\begin{tabular}{lcccc}
\hline Groups & N & $\begin{array}{c}\text { Height at the time } \\
\text { of diagnosis (SDS) }\end{array}$ & $\begin{array}{c}\text { Final stature } \\
\text { (SDS) }\end{array}$ & $\begin{array}{c}\text { Height at the time of } \\
\text { diagnosis/final stature (SDS) }\end{array}$ \\
\hline G1: Prepubertal child with short stature & 4 & $-3 \pm 0.28$ & $-1.52 \pm 0.21$ & $1.48 \pm 0.37$ \\
G2: Prepubertal child with normal height & 5 & $-1.07 \pm 1.27$ & $-1.71 \pm 1.37$ & $-0.64 \pm 1.11$ \\
G3: Pubertal child with short stature & 6 & $-3.72 \pm 0.77$ & $-2.82 \pm 1.31$ & $0.9 \pm 0.38$ \\
G4: Pubertal child with normal height & 18 & $0.31 \pm 1.09$ & $-0.6 \pm 1.09$ & $-0.91 \pm 0.22$ \\
\hline
\end{tabular}

N: number of patients; SDS: standard deviation score.

TABLE 2. Evolution of height in prepubertal children with short stature at the time of diagnosis (group 1)

\begin{tabular}{lcccccc}
\hline Patient & Sex & $\begin{array}{c}\text { CA } \\
\text { (years old) }\end{array}$ & $\begin{array}{c}\text { CA-BA } \\
\text { (years old) }\end{array}$ & $\begin{array}{c}\text { Height at the time } \\
\text { of diagnosis (SDS) }\end{array}$ & $\begin{array}{c}\text { Menarche } \\
\text { (years old) }\end{array}$ & $\begin{array}{c}\text { Final stature } \\
\text { (SDS) }\end{array}$ \\
\hline 1 & 13.1 & 6.3 & -2.98 & 14.6 & -1.59 \\
2 & F & 11.9 & 5.9 & -3.1 & & -1.2 \\
3 & M & 7.25 & 2.25 & -3.28 & 13.6 & -1.67 \\
4 & F & 12.5 & 4.5 & -2.62 & 13.9 & -1.6 \\
\hline
\end{tabular}

CA: chronological age; BA: bone age; SDS: standard deviation score. 
Girls experienced the menarche 1.5 years later than what has been described for the normal population as per Tanner et al.

Table 3 shows the clinical characteristics of G3. Patient 2 showed a very poor treatment adherence. Patient 4 was diagnosed at 15.1 years old, once she had completed puberty. Patients 3 and 6 had extreme short stature at the time of diagnosis, so they were treated with gonadotropin-releasing hormone $(\mathrm{GnRH})$ analogues. Patient 3 started GnRH analogues at 10 years old, with Tanner stage III and a height of -3.73 SDS, and discontinued treatment at 11.8 years with a $B A=12.5$ years. She experienced menarche at 13 years old and her final stature was -3.13 SDS.

Patient 6 reached a normal final stature for the population, but shorter than her genetic range $(-0.76 \mathrm{SDS})$. It is striking that, at the time of diagnosis (13.8 years), she had experienced menarche with a 6-year delay in BA and a height of -3.77 SDS. She received GnRH analogues for 10 months, and discontinued treatment due to problems with the supply; her final stature was -1.9 SDS.

Five girls $(6.3 \%)$ had precocious puberty (PP) at the time of diagnosis (Table 4).

\section{DISCUSSION}

SAH in children causes growth failure and a marked delay in skeletal maturation as a result of a delayed ossification and mineralization, combined with the reduction and downregulation of growth hormone and insulin-like growth factor. ., $^{\circ}$

Once replacement therapy with levothyroxine is started, children experience a compensatory growth phase, during which the rate of skeletal maturation exceeds the height gain, thus resulting in a deficit of final stature. Such phenomenon is worsened by the onset of central puberty, which often takes place shortly after the initiation of hormone replacement. ${ }^{7}$

The objective of this study was to describe the population of pediatric patients with SAH caused by CLT and analyze its impact on their height close to final stature based on the SDS for height and pubertal stage at the time of diagnosis in order to detect the groups of patients at a greater risk for adult short stature.

A clinical presentation without goiter showed greater height involvement. Surely, this was due to the presence of a clinical sign that alerted about the thyroid disease.

TABLE 3. Evolution of height in pubertal children with short stature at the time of diagnosis (group 3)

\begin{tabular}{lcccccc}
\hline Patient & Sex & $\begin{array}{c}\text { CA } \\
\text { (years old) }\end{array}$ & $\begin{array}{c}\text { CA-BA } \\
\text { (years old) }\end{array}$ & $\begin{array}{c}\text { Height at the time } \\
\text { of diagnosis (SDS) }\end{array}$ & $\begin{array}{c}\text { Tanner stage at the } \\
\text { time of diagnosis }\end{array}$ & $\begin{array}{c}\text { Final stature } \\
\text { (SDS) }\end{array}$ \\
\hline 1 & F & 13.4 & 5.4 & -3.06 & III & -2.27 \\
2 & F & 14.5 & 3.5 & -4.16 & IV & -3.89 \\
3 & F & 9.3 & 4.3 & -4.68 & II & -3.1 \\
4 & M & 15.1 & 7.3 & -3.13 & IV T $=20 \mathrm{~mL}$ & -2.69 \\
5 & M & 14.7 & 6.9 & -2.9 & III T $=12 \mathrm{~mL}$ & -1.66 \\
6 & F & 13.9 & 6.1 & -3.7 & IV & -1.9 \\
\hline
\end{tabular}

CA: chronological age; BA: bone age; SDS: standard deviation score; T: testicular volume (mL).

TABLE 4. Patients with central precocious puberty

\begin{tabular}{lccccccc}
\hline & Patient & $\begin{array}{c}\text { CA at the time } \\
\text { of diagnosis } \\
\text { (years old) }\end{array}$ & $\begin{array}{c}\text { Height at the } \\
\text { time of diagnosis } \\
\text { (SDS) }\end{array}$ & $\begin{array}{c}\text { Tanner stage } \\
\text { at the time } \\
\text { of diagnosis }\end{array}$ & $\begin{array}{c}\text { Menarche } \\
\text { (years old) }\end{array}$ & $\begin{array}{c}\text { Final } \\
\text { stature } \\
\text { (SDS) }\end{array}$ & $\begin{array}{c}\text { Lower } \\
\text { limit of the } \\
\text { GR (SDS) }\end{array}$ \\
\hline Before & 1 & 11.8 & -0.16 & IV & 10 & -2.55 & -3.53 \\
hypothyroidism & 2 & 10.5 & -0.24 & IV & 10 & -1.75 & -2.71 \\
diagnosis & 3 & 10 & -0.2 & IV & 10 & -2.65 & -2.2 \\
\hline $\begin{array}{l}\text { After } \\
\text { hypothyroidism }\end{array}$ & 4 & 8.33 & 1.88 & III & 9.4 & -0.88 & -0.89 \\
diagnosis & 5 & 6.25 & 0.43 & I & 9 & -0.16 & -1.48 \\
\hline
\end{tabular}

CA: chronological age; SDS: standard deviation score; GR: genetic range. 
A delay in BA at the time of diagnosis was not a predictor of a higher rate of growth because, after starting hormone replacement therapy, skeletal maturation advanced rapidly, which is consistent with what has been described by Pantsiouou et al. ${ }^{8}$

In our study, like in the one by Chiesa et al., ${ }^{9}$ it was demonstrated that, in addition to height deficit at the time of diagnosis, an advanced puberty was also a determining factor of final stature.

Different adjuvant growth therapies have been proposed, including $\mathrm{GnRH}$ analogues, growth hormone-releasing hormone (GHrh) or aromatase inhibitors (AIs). Nebesio et al. compared the final stature of 13 children with severe hypothyroidism (TSH $>150 \mu \mathrm{IU} / \mathrm{mL}$ ); 6 of them received adjuvant treatments (AIs, GHrh and / or GnRH analogues) and 7, levothyroxine only. No differences were observed among the groups. ${ }^{10}$

They reported on 6 children treated with GnRH analogues who had severe growth failure, higher chronological age, pubertal progression, and advance of $\mathrm{BA}$, who reached the same height as 17 children with a lower height involvement at the time of diagnosis treated with levothyroxine only. ${ }^{11}$

Reports of isolated cases ${ }^{12-15}$ have demonstrated that the combined therapy with GHrh and GnRH analogues, in addition to levothyroxine, achieved an important increase in the SDS for height in adolescents with severe hypothyroidism and a poor prognosis for their final stature.

The published studies about the effectiveness of adjuvant growth therapies in patients with $\mathrm{SAH}$ during childhood and adolescence have several limitations, such as the small number of patients, their retrospective design, different follow-up durations, different levothyroxine initial doses and subsequent adjustments, and the lack of standard adjuvant therapies.

Although the limitation of our study is the small number of patients in each subgroup that reached their final stature, we believe that the late diagnosis of severe hypothyroidism in pediatrics has a negative impact on it, especially in pubertal children with short stature at the time of diagnosis, for whom adjuvant growth therapies may be considered to improve their height prognosis.
Randomized, controlled, and prospective studies are required to elucidate the modifiable factors related to the loss of potential height in children with SAH.

\section{CONCLUSION}

The late diagnosis of severe hypothyroidism in pediatrics has a negative impact on final stature, especially in those who were pubertal patients at the time of diagnosis.

\section{REFERENCES}

1. Caturegli P, Kimura H, Rocchi R, Rose NR. Autoinmune thyroid diseases. Curr Opin Rheumatol. 2007; 19(1):44-8.

2. De Vries L, Bulvik S, Phillip M. Chronic autoimmune thyroiditis in children and adolescents: at presentation and during long-term follow-up. Arch Dis Child. 2009; 94(1):33-7.

3. Comité Nacional de Crecimiento y Desarrollo. Guía para la evaluación del crecimiento físico. 3.ra ed. Buenos Aires: Sociedad Argentina de Pediatría; 2013.

4. Chaler EA, Fiorenzano R, Chilelli C, Llinares V, et al. Age-specific thyroid hormone and thyrotropin reference intervals for a pediatric and adolescent population. Clin Chem Lab Med. 2012; 50(5):885-90.

5. Brent GA. The molecular basis of thyroid hormone action. $N$ Engl J Med. 1994; 311(13):847-53.

6. Robson H, Siebler T, Shalet SM, Williams GR. Interactions between GH, IGF-1, glucocorticoids, and thyroid hormones during skeletal growth. Pediatr Res. 2002; 52(2):137-47.

7. Boersma B, Otten BJ, Stoelinga GB, Wit JM. Catch-up growth after prolonged hypothyroidism. Eur J Pediatr. 1996; 155(5):362-7.

8. Pantsiouou S, Stanhope R, Uruena M, Preece MA, et al. Growth prognosis and growth after menarche in primary hypothyroidism. Arch Dis Child. 1991; 66(7):838-40.

9. Chiesa A, Gruñeiro de Papendieck L, Keselman A, Heinrich JJ, et al. Final height in long-term primary hypothyroid children. J Pediatr Endocrinol Metab. 1998; 11(1):51-8.

10. Nebesio T, Wise M, Perkins S, Eugster E. Does clinical management impact height potential in children with severe acquired hypothyroidism? J Pediatr Endocrinol Metab. 2011; 24(11-12):893-6.

11. Quintos JB, Salas M. Use of growth hormone and gonadotropin releasing hormone agonist in addition to L-thyroxine to attain normal adult height in two patients with severe Hashimoto's thyroiditis. J Pediatr Endocrinol Metab. 2005; 18(5):515-21.

12. Teng L, Bui H, Bachrach L, Lee P, et al. Catch-up growth in severe juvenile hypothyroidism: treatment with a GnRH analog. J Pediatr Endocrinol Metab. 2004; 17(3):345-54.

13. Minamitani K, Murata A, Ohnishi H, Wataki K, et al. Attainment of normal height in severe juvenile hypothyroidism. Arch Dis Child. 1994; 70(5):429-30.

14. Bruder JM, Samuels MH, Bremer WJ, Ridgway EC, et al. Hypothyroidism-induced macroorchidism: use of a gonadotropin-releasing hormone agonist to understand its mechanism and augment adul stature. J Clin Endocrinol Metab. 1995; 80(1):11-6. 